Session 3286

\title{
A Simple Workshop on Project Teams for Secondary School Technology and Science Teachers and Their Students
}

\author{
Michael Marcus \\ Penn State University - York Campus
}

\begin{abstract}
As a faculty member teaching in Engineering and Engineering Technology Programs, I was interested in finding simple ways to promote interest in these fields for middle school and high school students. I have attended a "Recruitment and Retention Strategies" conference supported by NSF to come up with some ideas. In addition, I have attended ASEE presentations on "Promoting ET thru K-12 projects" and I have been a reviewer of papers on this topic.

I have visited many of the local high schools and given presentations during career days and also presented at our campus during open house activities, but I was looking for a different approach. Many of the projects such as "Project Lead the Way" ${ }^{1}$ are great but they are quite involved and take a significant commitment. What I describe in this paper is a simple project that I used involving teachers and their students that I thought was quite successful. This project was easily manageable for a faculty member acting alone or with a few other faculty members.

Some of the teachers and students involved in the project were from schools with large minority populations and as a result of this a small grant was obtained. As an incentive, the teachers received credit for the workshop and were given robotic equipment from LEGO MindStorms for their classroom that was used during the workshop.

\section{Introduction}

The first part of this project involved York area secondary school technology and science teachers participating in a workshop on team problem solving and providing them with robotic engineering technology kits for their use in the classroom.

The second part of this project involved one of the teachers from the workshop bringing in thirty students to Penn State York and applying these team problem solving techniques using the Lego kits; also, a workshop on Computer Aided design was presented. In addition, these students were presented admissions and financial information for college. Funding for this project came from a local entrepreneur fund, and a Penn State University Equal Opportunity Planning Committee ${ }^{2}$ (EOPC) fund.
\end{abstract}




\section{Part I - Professional Development Workshop for Teachers}

Secondary school technology and science teachers were invited to participate in a workshop on team problem solving. With the help of the Director of Continuing Education, the teachers received "Act 48", credit for the workshop. The teachers learned a methodology for problem solving by participating on a project team to derive solutions to an actual electromechanical design problem using a hematology analyzer from industry.

For this design problem, blood is collected from the vein and placed in a hollow tube about $8 \mathrm{~cm}$ in length and $2 \mathrm{~mm}$ in diameter. A float is inserted into the tube that has the same specific density as the white cells and, thus, expands the white cell band length. The tube is then centrifuged at high speed and settles in layers according to the density of the different components in the blood, as shown in Figure 1. These components consist of red blood cells, white blood cells, platelets, and plasma. The glass tube is coated with special chemicals to accent the color of the different components of the blood. This tube is then placed in an instrument that scans each tube eight times with a laser beam to measure the band lengths and then calculates the value of each of these components in the blood.

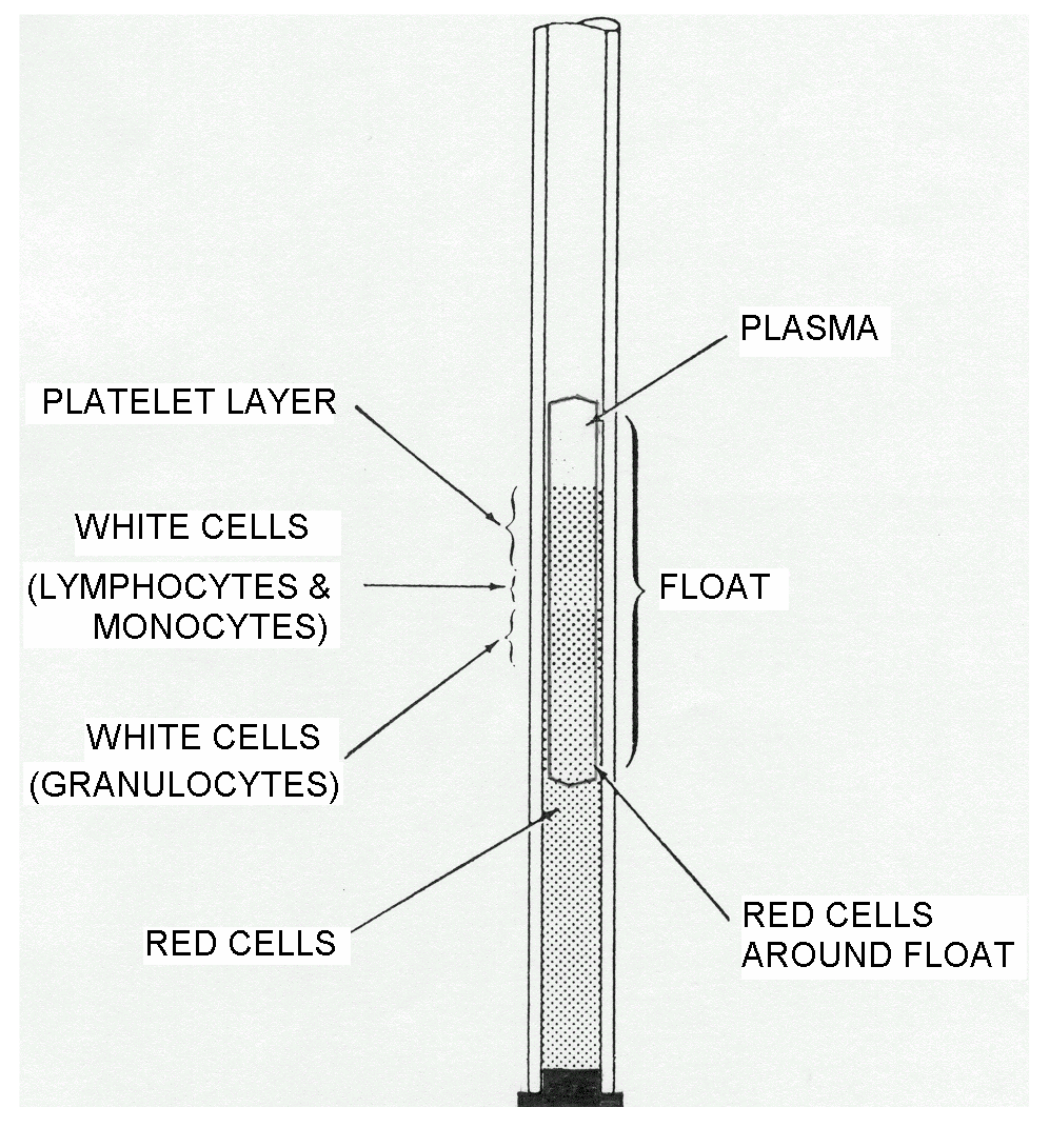

Figure 1. Centrifuged Separated Layers 


\section{The Team Assignment}

The objective of the team assignment is for the students to come up with a mechanism for holding this glass tube in place and rotating the tube eight times so that the beam can scan the tube each time.

The steps involved in the workshop consisted of the following:

1. Determine the nature of the problem and create specifications.

2. Brainstorming to compile a list of possible solutions.

3. Select three best possible solutions.

4. Sketch one of the solutions.

5. Suggest ways to test solutions.

This method can be used in any number of technology courses and will help students prepare for problem solving and working in a team environment.

The teachers then applied these techniques to build and program a robot using Lego MindStorms ${ }^{4}$ that would change directions when it bumped into something.

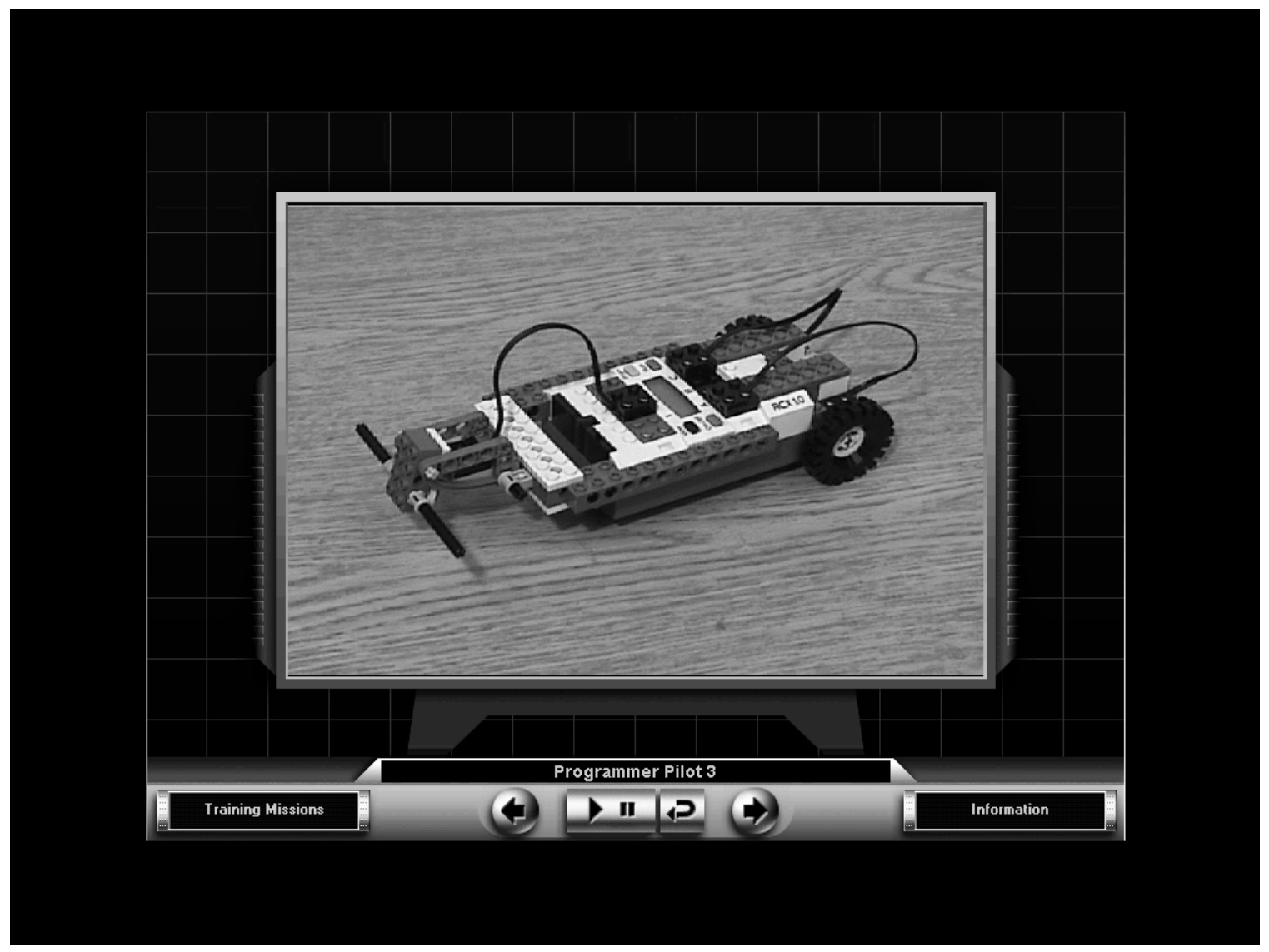

Figure 2 . Bumper Car 


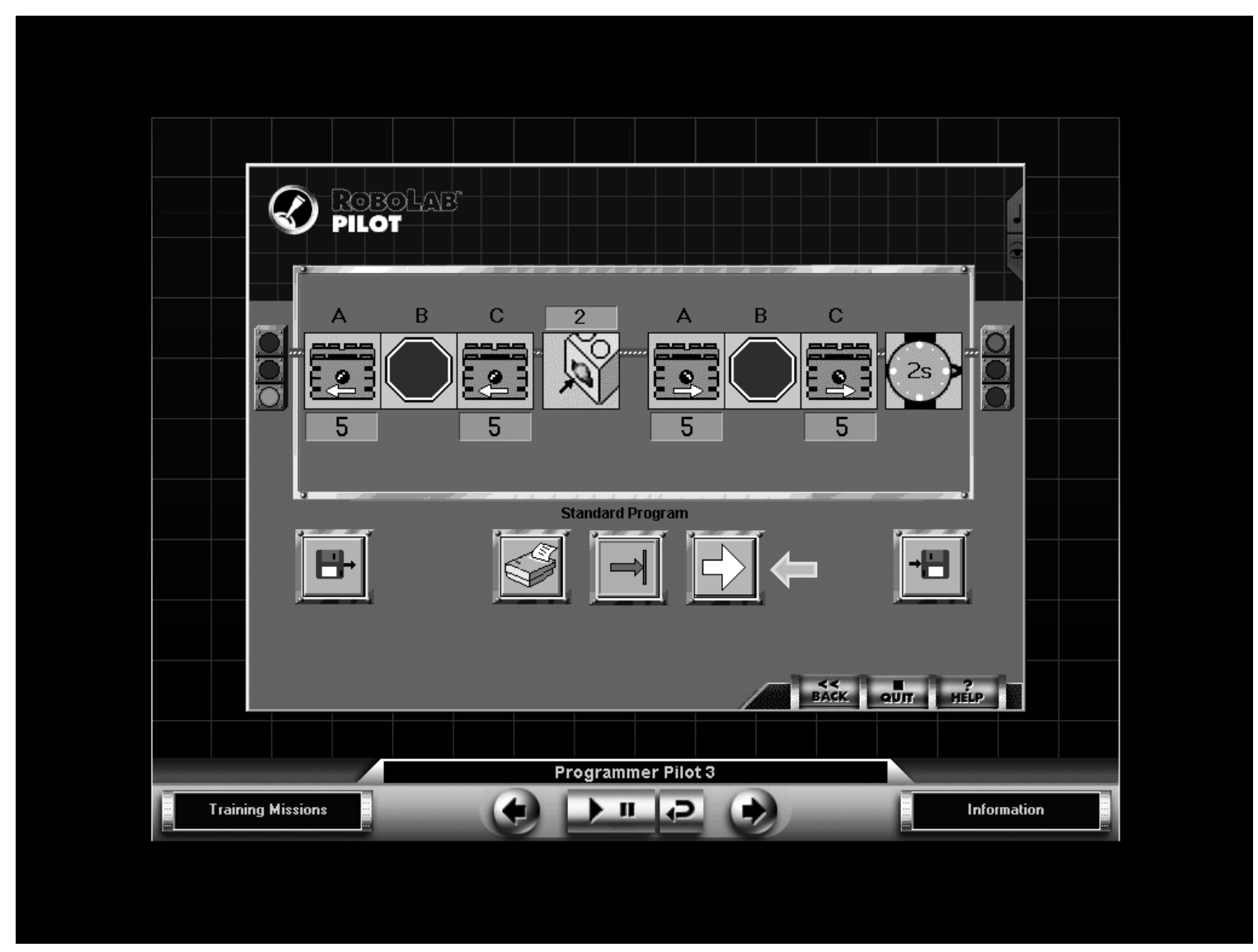

Figure 3. Program for bumper car

\section{Part II - Workshop for Students}

Thirty students from William Penn High School attended Penn State York for a workshop. The students then broke into two groups and participated in two workshops. The first workshop was presented by a Penn State York faculty member on Computer Aided Design using Solid Works. The second workshop was using LEGO MindStorms to build and program a robot. Each of the eight teams built and programmed a robot that would go forward and then when it bumped into something it would reverse and go backwards for five seconds and then stop. The teacher applied these techniques to teams of students to have them build and program the robots.

\section{Conclusion}

The teachers that received the training on group problem solving were able to apply these techniques when they built the robots. The teacher that brought in the thirty students from William Penn High School was then able to apply these methods for her class when they built the robots. The robot kits were given to the schools so they can continue using these kits. All of the eight groups of students were successful in completing the building and programming of the robots. They seemed to have fun and worked well as groups. We were responsible for submitting an outcomes assessment to EOPC as part of the grant requirements. If only limited 
funds are available, I thought electronic project kits for under thirty dollars called "Electronic Snap Circuit" ${ }^{5}$ were excellent.

\section{Bibliography}

1. Project Lead The Way - www.pltw.org

2. Equal Opportunity Planning Committee - http://www.equity.psu.edu/eopc/

3. Act 48 - http://www.psu.edu/registrar/act48/act48.html

4. LEGO MindStorms - www.pitsco.com

5. Electronic Snap Circuits - www.elenco.com

MICHAEL MARCUS is an Associate Professor of Engineering at Pennsylvania State University - York Campus. He worked in industry for seventeen years in the Biomedical Instrumentation field and became a Senior Project Engineer where he managed project teams consisting of other engineers and technicians. His research interests are in teaching methodology of project teams, biomedical instrumentation, and digital image processing of hematological samples. 